\title{
VISCERAL LEISHMANIASIS;
}

\author{
Validity of polymerase chain reaction in the diagnosis
}

Dr. Muhammad Usman, Dr. Fayyaz Hussain, Dr. Muhammad Kashif Baig

ABSTRACT... Leishmaniasis is a disease caused by protozoan parasite of genus Leishmania which is transmitted through bites of infected sand flies. It has been reported that Polymerase chain reaction (PCR) is more sensitive and specific test for the diagnosis of visceral leishmaniasis than bone marrow examination. This recent study is a renewed effort to validate the role of PCR in the diagnosis of visceral leishmaniasis. Objectives: The objective of this study was to determine the sensitivity and specificity of PCR in the diagnosis of visceral leishmaniasis. Duration of study: $25^{\text {th }}$ March 2009 to 24th March 2010. Setting: Armed forces institute of pathology, Rawalpindi. Study design: Cross sectional (Validation) study. Materials and Methods: A total number of 59 patients of visceral leishmanaisis diagnosed on bone marrow examination with equal number of negative controls were studied. The subjects were tested for the presence of visceral leishmaniasis by polymerase chain reaction. Results: All the 59 patients were also found to be positive for visceral leishmaniasis by PCR. None of the negative control was positive on PCR. Conclusions: The study validates that PCR is equally sensitive and specific test to bone marrow examination in the diagnosis of visceral leishmaniasis.

\section{Key words: Visceral leishmaniasis, PCR, Sandfly.}

Article Citation

Usman M, Hussain F, Baig MK. Visceral leishmaniasis; validity of polymerase chain reaction in the diagnosis. Professional Med $\mathrm{J}$ 2013;20(6): 884-890.

\section{INTRODUCTION}

Leishmaniasis is a group of diseases caused by protozoan parasites of the genus Leishmania'. It is transmitted by the bite of infected sandflies including flies in the genus Lutzomia in the New World and Phlebotomus in the Old World ${ }^{2}$.

Visceral leishmaniasis is the most severe form in which the parasites migrate to the vital organs like liver, spleen and bone marrow ${ }^{3}$. Patient usually presents with unexplained fever, generalized weakness, weight loss, nausea, vomiting ${ }^{4}$. On examination massive splenomegaly is almost always present along with hepatomegaly and lymphadenopathy.

The annual incidence of visceral leishmaniasis worldwide is 0.5 million $^{5}$. Of these $90 \%$ cases occur in the Indian subcontinent and Sudan ${ }^{6}$. Other endemic regions are Mediterranean and Africa. In Pakistan, visceral leishmanaisis is endemic in Azad Kashmir and some areas of Khyber Pakhtoonkhwa ${ }^{7}$. Cutaneous leishmaniasis is prevalent in Baluchistan, Interior Sind, and Multan ${ }^{8}$.
Mostly peripheral blood film shows anemia, leucopenia and thrombocytopenia. Bone marrow examination is gold standard for the diagnosis of visceral leishmaniasis in which Leishmania donovani bodies (LD bodies) are seen in the aspirate ${ }^{9}$. Other methods for the diagnosis of visceral leishmaniasis include splenic aspirate and lymph node biopsy.

In recent years, PCR has proved to be highly sensitive and specific test for the diagnosis of visceral leishmaniasis ${ }^{10}$. In visceral leishmaniasis, most of the times, bone marrow aspirate is a dry tap and it becomes difficult to find LD bodies in the smear. So in these circumstances, PCR is helpful for the diagnosis of the disease.

Treatment of the disease has been based on pentavalent antimony drugs e.g. Sodium stibogluconate. Human Immunodeficiency Virus (HIV) co-infected patients do not respond well to antimonials so amphotericin B is the drug of choice. Other drugs used are paromomycin and miltefosine ${ }^{11}$.

This recent study of determining sensitivity and 
specificity of PCR in the diagnosis of visceral leishmaniasis is the first of its kind in this part of world. The data from this study would be helpful in validating or refuting the role of PCR in the diagnosis of the disease.

\section{MATERIAL AND METHODS}

Diagnosed patients of visceral leishmaniasis were selected from AFIP on designated days by consecutive sampling. An equal number of age and sex matched controls were selected from AFIP. An informed consent was obtained and a proforma was completed for all individuals highlighting the personal details (name, gender, age, and ethnicity), relevant clinical history and physical findings.

\section{Specimen collection}

After patient reassurance and consent, bone marrow examination was done and aspirate $(1-2 \mathrm{ml})$ was taken for microscopy and PCR. Ethylenediamine tetra-acetic acid (EDTA) was used as an anticoagulant; at concentrations of $1.5+0.5 \mathrm{mg} / \mathrm{ml}$.

\section{Bone marrow examination}

Bone marrow aspirate $(0.5 \mathrm{ml})$ was taken from posterior iliac spine in patients above 02 years and from tibia in patients below 02 years under strict sterile precautions. Slides were air dried and stained with Leishman stain and then microscopy was done for the detection of Leishmania donovani amsatigotes (LD bodies).

\section{Polymerase Chain Reaction (PCR)}

Bone marrow aspirate $(0.5-1 \mathrm{ml})$ was taken for PCR. PCR was performed using the following steps:
a) DNA Extraction
b) DNA amplification
c) Polyacrylamide Gel Electrophoresis (PAGE)
d) DNA Extraction

\section{(i) Kit method}

$300 \mu \mathrm{L}$ bone marrow aspirate was taken in $1.5 \mathrm{ml}$ eppendorf.

900 $\mu \mathrm{L}$ Red Blood Cells Lysis solution (Ammonium chloride, EDTA, Sodium Bicarbonate) was added. Mixed well and left at room temperature for 03-04 minutes and then centrifuged at $13000 \mathrm{rpm}$ for 30 seconds.

Then supernatant was discarded leaving behind pallet. Mixed well and left at room temperature for 03-04 minutes.

Vortexted for 15 seconds and then added $300 \mu \mathrm{L}$ White blood Cells lysis solution (Tris, EDTA, Sodium Dodecyl Sulphate) and mixed well.

Then added $100 \mu \mathrm{L}$ protein precipitating solution (Ammonium acetate) and vortexed for 20 seconds and centrifuged at 13000 rpm for 01 minute.

Then supernatant was shifted into another eppendorf and $300 \mu \mathrm{L}$ Isopropanol was added.

Inverted 50 times until DNA was precipitated and thread was seen.

Washed with $300 \mu \mathrm{L} 70 \%$ ethanol and centrifuged at 13000 rpm for 01 minute.

The supernatant was discarded and eppendorf was kept at room temperature for 03- 04 minutes.

Hydration solution was added and the tube was kept at $56^{\circ} \mathrm{C}$ for 15 minutes.

Vortexed and then centrifuged for few seconds. DNA was stored at $04^{\circ} \mathrm{C}$.

\section{(ii) Manual method}

This method was used to extract DNA from bone marrow slides.

Dropped a few drops of Lysis solution (Tris 50mmol, EDTA $20 \mathrm{mmol}$, SDS 02\%) on the slide and scrubbed 
off the smear and shifted it to an $1.5 \mathrm{ml}$ eppendorf.

500-700 $\mu \mathrm{L}$ lysis solution was added.

25-30 $\mu \mathrm{L}$ Proteinase $\mathrm{K}(20 \mathrm{mg} / \mathrm{ml})$ was added. Vortexed for a few seconds and then kept it at $37^{\circ} \mathrm{C}$ overnight.

$250 \mu \mathrm{L}$ phenol and chloroform were added. Vortexed and then centrifuged at $11000 \mathrm{rpm}$ for 02 minutes.

The precipitate was discarded and procedure was repeated.

Then $500 \mu \mathrm{L}$ chloroform was added. Vortexed and centrifuged at $11000 \mathrm{rpm}$ for 02 minutes.

The supernatant was shifted into another eppendorf and added $150 \mu \mathrm{L}$ ammonium acetate and filled the tube with absolute ethanol.

Inverted the tube for 20-30 times until DNA was precipitated and thread was seen and then centrifuged at 11000 rpm for 02 minutes.

The supernatant was discarded and $01 \mathrm{ml}$ absolute ethanol was added and centrifuged at $11000 \mathrm{rpm}$ for 02 minutes.

Supernatant was discarded and kept the eppendorf at room temperature for 03-05 minutes.

Hydration solution was added and kept it at $56^{\circ} \mathrm{C}$ for 15 minutes. Vortexed and centrifuged for 15 seconds.

DNA was stored at $04^{\circ} \mathrm{C}$.

\section{b) DNA amplification}

DNA was taken in a PCR vial. Following reagents were added:

PCR mix (dNTPs, MgCl2, KCl, Tris, gelatin, Spermidins $20 \mu \mathrm{L} /$ vial, Taq polymerase $0.5 \mathrm{U} /$ vial and leishmania specific primers $01 \mu \mathrm{L} /$ vial.
PCR amplification included a first denaturation step of 2 minutes at $94^{\circ} \mathrm{C}$ followed by 40 cycles of $94^{\circ} \mathrm{C}$ for 01 minute, $45^{\circ} \mathrm{C}$ for 01 minute and $72^{\circ} \mathrm{C}$ for 01 minute in a thermal cycler (Figure 7). Final extension was carried out at $72^{\circ} \mathrm{C}$ for 03 minutes.

Negative and positive controls were also applied.

\section{c) $6 \%$ PolyAcrylamide Gel Electrophoresis (PAGE)}

$50 \mu \mathrm{L} 10 \%$ APS (Ammonium Per Sulphate) and 10 $\mu \mathrm{L}$ TEMED (Tetra Methyl Ethylene Diamine) were added in $5 \mathrm{ml} 6 \%$ polyacrylamide solution.

Mixed well and was put into electrophoresis apparatus and kept at room temperature for 20 minutes.

Then $3 \mu \mathrm{L}$ of amplified product was mixed with $3 \mu \mathrm{L}$ of bromophenol blue (tracking dye) and then loaded into wells.

Electrophoresis was carried out at 200V for 20 minutes.

Gel was stained with $0.1 \% \mathrm{AgNO}$ for 15 minutes followed by counter staining with $1.5 \% \mathrm{NaOH}$ mixed with formalin.

Gel was preserved on a filter paper.

Visual assessment of the bands of visceral leishmaniasis of the patients was done by comparing with normal and positive controls.

\section{STATISTICAL ANALYSIS}

All the collected data was entered in statistical program for social sciences (SPSS) version 14. The analyzed variables included numerical data like age, hepatomegaly, splenomegaly for which mean and standard deviation were calculated. Percentages were used for qualitative data like gender, results of bone marrow and PCR. Sensitivity, specificity. Positive predicted value, negative predicted value were calculated and represented by tables and charts. 


\section{RESULTS}

A total of 59 diagnosed patients of visceral leishmaniasis were enrolled in the study. PCR of all the diagnosed patients of visceral leishmaniasis $(n=59)$,

\begin{tabular}{|c|c|c|c|c|}
\hline $\begin{array}{c}\text { No. of } \\
\text { patients }\end{array}$ & $\begin{array}{c}\text { Minimum } \\
\text { age }\end{array}$ & $\begin{array}{c}\text { Maximum } \\
\text { age }\end{array}$ & $\begin{array}{c}\text { Mean } \\
\text { age }\end{array}$ & $\begin{array}{c}\text { Standard } \\
\text { Deviation }\end{array}$ \\
\hline 59 & $\begin{array}{c}03 \\
\text { months }\end{array}$ & 08 years & $\begin{array}{c}22 \\
\text { months }\end{array}$ & 16.5 \\
\hline \multicolumn{3}{|c}{ Table-l. Summary of age statistics } \\
\hline
\end{tabular}

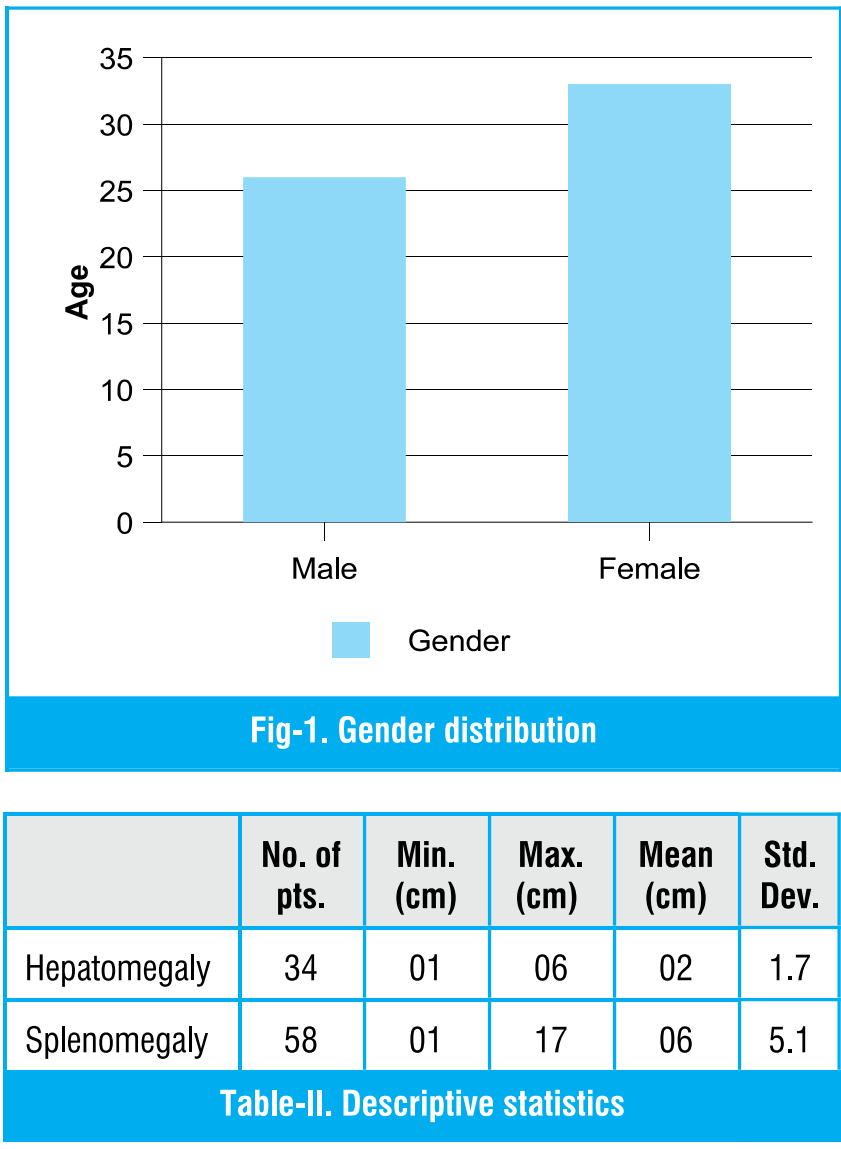

\begin{tabular}{|c|c|c|}
\hline \multirow{3}{*}{$\begin{array}{l}+\mathrm{ve} \\
\text { PCR } \\
\text {-ve }\end{array}$} & \multicolumn{2}{|c|}{ Bone marrow } \\
\hline & 59 & - \\
\hline & - & 59 \\
\hline
\end{tabular}

on bone marrow examination, were done along with equal number of negative controls. All negative controls were negative by PCR, whereas all of the positive patients on bone marrow examination were also positive by PCR. Sensitivity, specificity, positive predicted value, negative predicted values were calculated using $2 \times 2$ table as shown subsequently in tables.
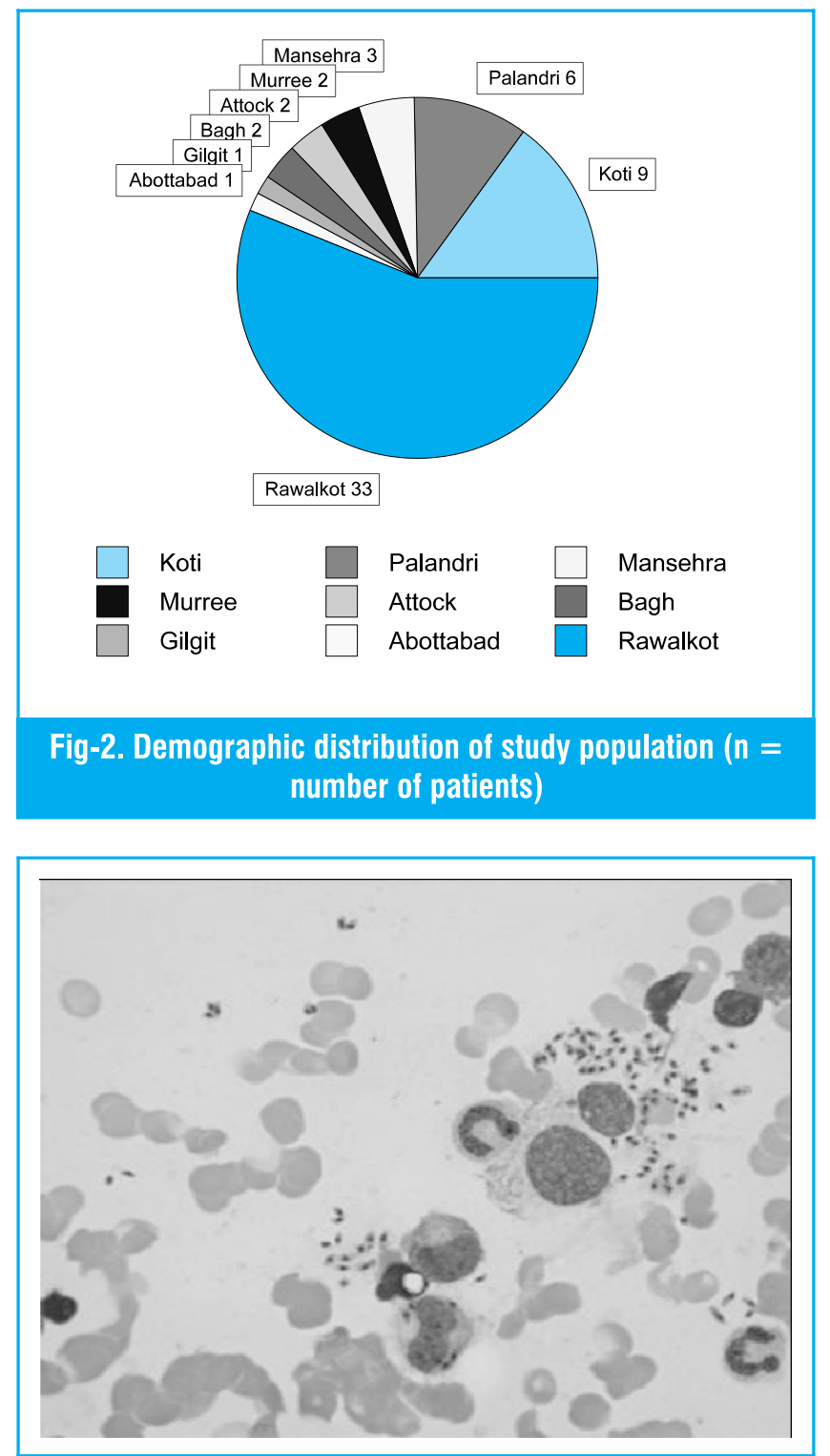

Fig-3. Bone marrow aspirate in visceral leishmaniasis 


\section{DISCUSSION}

Leishmaniasis is a major public health problem which is endemic in many countries in the tropics and subtropics. Leishmaniasis is considered to be a neglected emerging disease and one of the most important parasitic diseases. The disease occurs in varying presentations, from self limited and even self healing cutaneous form to fatal systemic disease, visceral leishmaniasis, also known as kala-azar. In Pakistan, visceral leishmaniasis is endemic in Azad Kashmir, Northern areas and Khyber Pakhtoonkhwa. While cutaneous leishmaniasis is prevalent in Baluchistan and Interior Sind ${ }^{8}$. Visceral leishmaniasis is the most fatal type of all which if left untreated can lead to death.

PCR has proved to be a useful method for the diagnosis of visceral leishmaniasis. It has almost $100 \%$ sensitivity and specificity ${ }^{12}$. PCR assay has the capability of detecting low levels of parasitemia from bone marrow aspirate, splenic aspirate, lymph node aspirate and peripheral blood sample. This capability is beneficial both in the diagnosis of the disease and for the prediction of the disease outcome, since a negative PCR result at the end of the treatment is likely to be associated with a favorable outcome.

Many studies have been done internationally on this subject. Our result is almost similar to those reported by Maurya $R$ and colleagues. Their results showed that 100 out 101 patients were positive by PCR while all negative controls $(n=150)$ were also PCR negative ${ }^{9}$.

In 1997, a prospective study was done in Netherland by Osman OF et al. They selected 60 positive controls and 90 negative controls. All the negative controls were negative by PCR, whereas all positive controls were positive.

Poonam Salotra and colleagues also had almost similar results in a study conducted in India, 102 out of 107 patients were positive by PCR with 96\% sensitivity. They used patients peripheral blood instead of bone marrow or splenic aspirate as they were invasive procedures ${ }^{13}$.

Antinori et al in the year 2007 also supported our results; they selected 68 patients of visceral leishmaniasis and sensitivities of the PCR were $95.7 \%$ for bone marrow aspirate samples. None of 229 negative controls were positive by PCR showing 100\% specificity $^{5}$.

In 2010, a prospective study was done in Brazil by Fraga TL et al. They also used peripheral blood of 40 patients and compared with other invasive procedures currently in use for the diagnosis of visceral leishmaniasis. They concluded that PCR of peripheral blood was $95.6 \%$ sensitive as compared to PCR of bone marrow aspirates $(91.1 \%)$ and culture $(26.7 \%)^{14}$.

Since our study is the first of its kind in Pakistan, therefore, no local studies were available on the subject for purpose of comparison of our results despite thorough search in the literature. Therefore, it is suggested that future studies on this subject should be done with sufficient time to allow the study of a larger sample, selected by randomization.

A prospective study on this subject like the one performed by Fraga TL et $\mathrm{a}^{14}$, must be undertaken in which they used peripheral blood as a tool for the diagnosis so that painful and invasive procedures like bone marrow could be avoided. Moreover, among the different techniques of PCR, real time PCR has the highest benefit for the patient because it is both qualitative and quantitative. It gives the parasite load at time of diagnosis and thus we can monitor the treatment response and thus modify our treatment regimens. Real time PCR also helps us in detecting minimal residual disease.

PCR is an extremely sensitive method, therefore, contamination from non-template PCR present in the 
lab environment (e.g. bacteria, viruses) presents a real problem in the results.

\section{CONCLUSIONS}

PCR is equally sensitive and specific test to bone marrow examination in the diagnosis of visceral leishmaniasis.

Copyright(C) 25 Sep, 2013.

\section{REFERENCES}

1. Mahnaz T, Katrin K, Amer AJ , Isabel M, Gabriele S, Safar $F$, et al. Leishmania major: genetic heterogeneity of Iranian isolates by single-strand conformation polymorphism and sequence analysis of ribosomal DNA internal transcribed spacer. Acta Trop 2006; 98 : 52-8.

2. Reithinger R, Dujardin JC. Molecular diagnosis of leishmaniasis: Current status and future applications. J Clin Microbiol 2007; 45: 21-5.

3. Tanoli ZM, Rai ME, Gandapur AS. Clinical presentation and management of visceral leishmaniasis. J Ayub Med Coll Abbottabad 2005; 17: 51-3.

4. Pizzuto M, Piazza M, Senese D, Scalamogna C, Calattini $S$, Corsico L, et al. Role of PCR in Diagnosis and Prognosis of Visceral leishmaniasis in Patients Coinfected with Human Immunodeficiency Virus Type 1. J Clinic Microbiol 2001; 39: 357-61.

5. Antinori S, Calattini S, Longhi E, Bestetti G, Piolini R, Magni $C$, et al. Clinical use of polymerase chain reaction performed on peripheral blood and bone marrow samples for the diagnosis and monitoring of visceral leishmaniasis in HIV-infected and HIVuninfected patients: a single-centre, 8-year experience in Italy and review of the literature. Clin Infect Dis 2007; 44: 1602-10.

6. Bora D. Epidemiology of visceral leishmaniasis in India. Natl Med J India 1999; 12: 62-68.
7. Altaf C, Ahmad P, Ashraf T, Anwar M, Ahmad I. Clinicopathological features of childhood visceral leishmaniasis in Azad Jammu \& Kashmir Pakistan. J Ayub Med Coll Abbottabad 2005; 17 :48-50. 8.

8. Rowland M, Munir A, Durrani N, Noyes H, Reyburn H. An outbreak of cutaneous leishmaniasis in an Afghan refugee settlement in north-west Pakistan. Trans R So Trop Med Hyg 1999; 93: 133-6.

9. Srivastava P, Dayama A, Mehrotra S, Sundar S. Diagnosis of visceral leishmaniasis. Trans R Soc Trop Med Hyg 2011; 105: 1-6.

10. Maurya R, Singh RK, Kumar B, Salotra P, Rai M, Sundar S. Evaluation of PCR for diagnosis of Indian kala-azar and assessment of cure. J Clin Microbiol 2005; 43: 3038-41. 11

11. Loiseau PM, Bories C. Recent strategies for the chemotherapy of visceral leishmaniasis. Curr Opin Infect Dis. 1999; 12: 559-64.

12. Ampuero J, Rios AP, Carranza CO, Romero GA. Genusspecific kinetoplast-DNA PCR and parasite culture for the diagnosis of localised cutaneous leishmaniasis: applications for clinical trials under field conditions in Brazil. Mem Inst Oswaldo Cruz 2009; 104: 992-7. 13.

13. Salotra P, Sreenivas G, Pogue GP, Lee N, Nakhasi HL, Ramesh $\mathrm{V}$, et al. Development of a species-specific PCR assay for detection of Leishmania donovani in clinical samples from patients with kala-azar and post-kala-azar dermal leishmaniasis. J Clin Microbiol 2001;39: 849-54.

14. Fraga TL, Brustoloni YM, Lima RB, Dorval ME, Oshiro $E T$, Oliveira $J$ et al. Polymerase chain reaction of peripheral blood as a tool for the diagnosis of visceral leishmaniasis in children. Mem Inst Oswaldo Cruz 2010; 105: 310-3. 


\section{AUTHOR(S):}

1. DR. MUHAMMAD USMAN

Assistant Professor

Pathology Department

Independent Medical College, Faisalabad

2. DR. FAYYAZ HUSSAIN

Assistant Professor

Combined Military Hospital, Rawalpindi

3. DR. MUHAMMAD KASHIF BAIG

Assistant Professor

Pathology Department

Independent Medical College, Faisalabad

\section{Correspondence Address:}

Dr. Muhammad Kashif Baig

Assistant Professor

Pathology Department

Independent Medical College, Faisalabad

baigs23@hotmail.com
Article received on: $20 / 09 / 2013$ Accepted for Publication: 13/10/2013 Received after proof reading: 03/12/2013

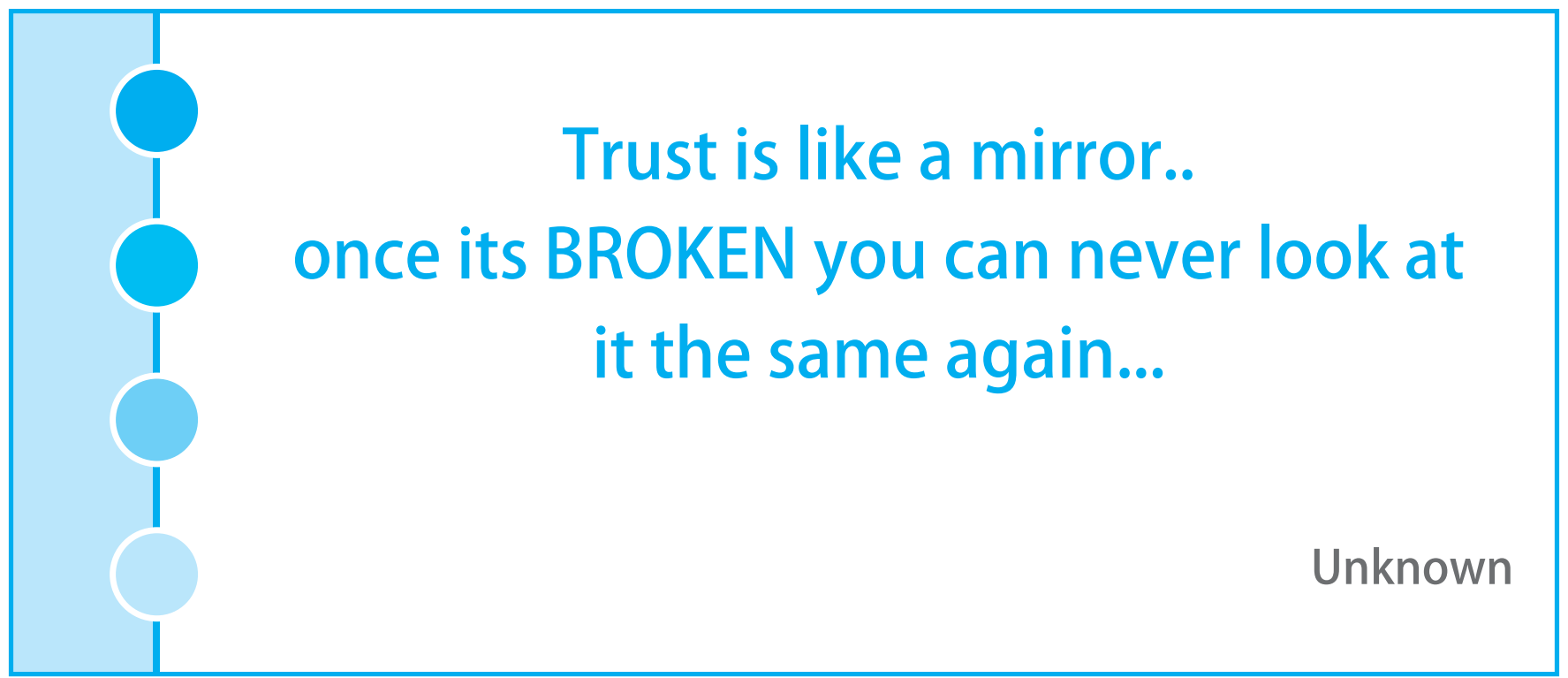

